from the Secretary, IAUPL, 19 Dunraven Street, London, W.1.

\section{Utilization of Fish and Agricultural Food Products}

A Conference on new developments in the utilization as food of fish and agricultural products will be held in Aberdeen during September 30October 2, under the auspices of the Society of Chemical Industry (Aberdeen Section and the Food and Agriculture Groups) and the Institute of Biology (Scottish Branch). The conference will be opened by Dr. F. N. Woodward, director of the Institute of Seaweed Research, and Dr. Norman Wright, scientific adviser to the Minister of Food, will give the elosing address. Topics to be discussed are: the feeding values of oats, straw and oat-milling products; the vacuum dehydration of foodstuffs ; freezing at sea; quality of sea-frozen cod; recent developments in fish by-products; supplements in the rations of livestock; distillery by-products, and their recovery and use as animal feeds; seaweeds and their constituents as foodstulfís; large-scale culture of microscopic algæ as food. There will be visits to the Ministry of Food Experimental Factory, the Torry Research Station and the Rowett Research Institute. A detailed programme and registration form will be available early in August from the Honorary Secretary (F. T. Walker), Institute of Biology, Scottish Branch, 25 Inverleith Gardens, Edinburgh 4.

\section{University of London}

THE title of professor emeritus in the University of London has been conferred upon the following on retiring from their respective chairs: Prof. H. V. A. Briscoe, inorganic chemistry at the Imperial College of Science and Technology; Prof. H. Munro Fox, zoology at Bedford College; Prof. Morris Ginsberg, sociology at the London School of Economics and Political Science; and Prof. Hyman Levy, mathematics at the Imperial College of Science and Technology. The following have been appointed to University readerships, tenable at the institutions indicated: Mr. D. G. MacRae, sociology at the London School of Economics and Political Science; Dr. R. G. White, bacteriology at the London Hospital Medical College; and Dr. J. H. Wilkinson, chemical pathology at Westminster Medical School.

\section{The Colonial Service: Recent Appointments}

The following appointments have recently been made in the Colonial Service : L. W. Harwood and N. Lamont (agricultural officers, Fiji), senior agricultural officers, Fiji ; R. J. M. Swynnerton (assistant director of agriculture (field services), Kenya), deputy director of agriculture, Kenya; R. P. St. John Watkin (chemist, Tanganyika), assistant government chemist, Nigeria; G. S. Brown (senior assistant conservator of forests, North Borneo), senior assistant conservator of forests, Federation of Malaya; W. B. Tevendale (geologist, Geological Survey Department, Gold Coast), senior geologist, Geological Survey Department, Gold Coast; D. A. R. Campbell, V. T. Domville and B. F. Topper (agricultural officers, Jamaica), senior agricultural officers, Jamaica; A. S. Martin (medical officer, Jamaica), assistant bacteriologist, Jamaica; R. Foster, scientific officer, Tanganyika; R. N. Gourlay, veterinary officer, Uganda; J. M. Ross, veterinary officer, Northern Rhodesia; R. N. Chrystal, forest entomologist, Cyprus; C. D. Cooke, veterinary officer, Nigeria; J. V. Thirgood, sylviculturist, Forestry Department, Cyprus.

\section{The Night Sky in August}

Full moon occurs on August 14d. 11h. 03m., U.T., and new moon on August 28d. 10h. $21 \mathrm{~m}$. The following conjunctions with the moon talke place: Aug. 2d. 18h., Venus $6^{\circ}$ N.; Aug. 6d. 03h., Saturn $8^{\circ}$ N.; Aug. 10d. 08h., Mars $3^{\circ}$ S. ; Aug. 25d. 01h., Jupiter $1^{\circ} \mathrm{N}$. In addition to these conjunctions with the moon, Mercury is in conjunction with Pollux on Aug. 3d. 23h., Mercury $7^{\circ}$ S., and also in conjunction with Uranus on Aug. 4d. 12h., being $0 \cdot 6^{\circ} \mathrm{S}$. of Uranus. On Aug. 31d. 01h., Venus is in conjunction with Spica and is $0 \cdot 1^{\circ} \mathrm{N}$. of the star. During the first part of the month Mercury is visible as a morning star, rising at $2 \mathrm{~h} .50 \mathrm{~m}$. and $4 \mathrm{~h}$. on August 1 and 15 , respectively, and is in superior conjunction on August 21. Venus, an evening star, sets at $21 \mathrm{~h} .10 \mathrm{~m}$., $20 \mathrm{~h} .35 \mathrm{~m}$. and $19 \mathrm{~h} .50 \mathrm{~m}$. at the beginning, middle and end of the month, respectively; the visible portion of the illuminated disk varies from 0.655 to 0.523 , and the stellar magnitude from $-3 \cdot 6$ to $-3 \cdot 9$, Mars sets very soon after midnight on August 1, and at $23 \mathrm{~h} .25 \mathrm{~m}$. and $22 \mathrm{~h} .45 \mathrm{~m}$. on August 15 and 31 , respectively; but as its declination is about $28^{\circ} \mathrm{S}$., it is not very favourably placed for observation in the British Isles. Jupiter is a morning star, rising at 2h. 25m., 1h. 45m. and 1h. on August 1, 15 and 31, respectively. It is easily identified (stellar mag. nitude $-1 \cdot 5$ ), and its motion from west to east of $\delta$ Geminorum during the month is obvious. Saturn, an evening star, sets at $22 \mathrm{~h} .35 \mathrm{~m} ., 2 \mathrm{~h} .40 \mathrm{~m}$. and $20 \mathrm{~h} .40 \mathrm{~m}$. at the beginning, middle and end of the month, respectively, stellar magnitude $0 \cdot 9$. Its slow easterly motion from $x$ Virginis is easily detected. The Perseid meteors attain a maximum about August 10-12, but bright moonlight will interfere with their observation. No occultations of stars brighter than magnitude 6 occur during August.

\section{Announcements}

The University of Leeds has conferred the title of reader in physics on Dr. F. E. Hoare, senior lecturer in the Department of Physics; Mr. E. W. Bennett has been appointed lecturer in the Department of Civil Engineering of the University.

The University of Cape Town is offering a scholar-

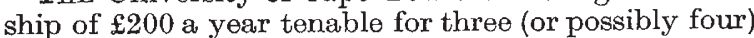
years to a student from Great Britain proposing to take a degree course at the University, beginning in March 1955. Applications should be forwarded not later than August 15 to the Secretary of the Association of Universities of the British Commonwealth, 5 Gordon Square, London, W.C.1.

THE Research Fund of the Chemical Society provides grants for the assistance of research in all branches of chemistry. About $£ 700$ a year is available for this purpose, the income being derived from a donation of the Worshipful Company of Goldsmiths, from the Perkin Memorial Fund, and from other sources. Applications for grants should be submitted to the General Secretary, Chemical Society, Burlington House, Piccadilly, London, W.1, on the appropriate form not later than November 5 .

THE third conference of the British Occupational Hygiene Society will be held at the London School of Hygiene and Tropical Medicine on November 1; it will be devoted to a discussion of radiation hazards in industry. Application forms for the conference can be obtained from the Hon. Secretary of the Society, Mr. P. C. G. Isaac, Public Health Engineering Laboratory, King's College, Newcastle upon Tyne. 